\title{
THE ROLE OF OPTIONAL DISCIPLINES IN DEVELOPING TRANSFERABLE COMPETENCES: A CASE OF ROMANIA
}

\author{
Adela Bradea, Karla Peter \\ University of Oradea, Romania \\ E-mail: adelabradea@yahoo.com, karla_barth@yahoo.com
}

\begin{abstract}
In Romania, the curriculum is traditionally strongly based on disciplines, the teachers being primarily specialised in one discipline only. Developing transferable competences requires new ways of teaching and learning, which transcend the traditional boundaries among disciplines. As they are being developed, these competences become important factors in the process of learning competences specific to certain disciplines, while also help the individual to adapt to the dynamics of a complex reality. Thus, given the importance of transferable competences, along with the reform of the curriculum, in the Romanian educational system optional disciplines were also included. The aim of this study was to analyse that, although there is a legislative framework, the development of activities that include multiple learning objectives or results that cross the traditional boundaries among disciplines, is still poor. The strategy used for the study was a complex one. It combined both quantitative research methods and qualitative ones: literature review (framework documents on educational policies), a statistic analysis, a questionnairebased survey. The results have demonstrated the need for change in school organization and culture, so that the transferable competences acquired become indeed competences for life.
\end{abstract}

Key words: curriculum, learning results, optional disciplines, transferable competences.

\section{Introduction}

Educational approaches based on key competences and the results of learning, which today are being included in more and more curricula in Europe, involve significant changes in the way of teaching. Transferable competences in their most general meaning are competences for life. They are those that help the individual to adapt to the dynamics of a complex reality, to the diversity of contexts in which reality manifests itself: professional and extra-professional, curricular or extracurricular, formal or non-formal, local or global, familiar or unknown etc. They are called transferable because they can be „transferred” over various professional or disciplinary fields, being present in each of them, but without being specific to any of them.

It is known that the overall effectiveness of performing a task does not result linearly from the sum of the general or specific competences that it involves, but rather from the working together of factors that transcend these competences. Thus, it has often been noticed that people with the same level and the same set of competences perform differently when the activity is considered as a whole; the factors that explain the differences are related to non-technical or non-disciplinary aspects such as personal development, lifelong learning, autonomy and responsibility, critical thinking and reflective practice, emotional intelligence, social communication and interaction, active citizenship.

As far as the transferability feature is concerned, experts have different opinions (CIDREE, 1998, Grundy, 1987, Ciolan, 2008, Voiculescu, 2011). Transferability is sometimes used to describe those competences that can be transferred from one discipline to another or/and 
PROBLEMS

OF EDUCATION

IN THE $21^{\text {st }}$ CENTURY

Volume 62,2014

from one context to another (other than the one they were learnt in). There are also experts who claim that transferability is essentially the extension to a larger or smaller scale of the set of contexts in which competences are learnt and practised. The transfer of specific competences is not excluded, but it is considered that transferable competences can be defined and constructed per se, as transprofessional and transdisciplinary competences (Voiculescu, 2011, p. 52).

Summing up the different approaches, D. Crutzen (2005, p. 10) highlights three significant characteristics of the transferability feature:

- a transferable competence is transdisciplinary, which means that these types of competences are formed through all disciplines, they are interdependent and they make a whole;

- a transferable competence allows transfer in different contexts and domains, which means that its shaping is strongly connected to the possibilities of transfer by analogy;

- a competence is more or less transferable depending on the extent of contexts it covers.

Thus, it can be said that developing these competences should enable the student to adapt to a continuously changing world, defined by the complexity and the interdependence of different economic, social and cultural dimensions.

\section{Problem of Research}

In Romania, there is a long tradition of a curriculum based on disciplines and most teachers are specialised in only one academic discipline, as it often happens in secondary education. Some of the transferable competences are learnt along with the disciplinary ones: sometimes in an explicit way (through inter-, trans- and multidisciplinary approaches), other times in an implicit way (as a side effect of extending and diversifying the contexts in which disciplinary competences are learnt and practised). Gradually, as transferable competences are learnt, they become factors that facilitate the learning of disciplinary competences, that is, the very factors that drive and explain school success (Voiculescu, 2011).

For an effective acquisition of transferable competences, teachers should develop integrated learning activities that enable students to learn more than one competence at the same time. The development of activities that include more learning objectives or results, and which cross the traditional boundaries among disciplines, can be found in the Romanian curriculum in the form of optional disciplines, which are part of a school based curriculum (SBC) (Skilbeck, 1984).

$\mathrm{SBC}$ is an educational project, which includes, with optional status, various disciplines suggested by the educational institution or chosen by it from a list compiled by the Ministry of Education. Each teacher has the opportunity to take part directly in the preparation of the curriculum, taking into account the actual conditions of the teaching activity. The optional disciplines can be designed in a monodisciplinary approach, that is, at the level of one curricular area, or at the level of more curricular areas. SBC is not subject to external, national evaluations and examinations. The teacher who prepares this type of curriculum has the duty to work out, besides educational objectives and instructive-educational contents, the competences the children are expected to acquire, as well as the performances they are expected to achieve, and the appropriate assessment tools.

A decision about SBC is made by the School Board after consulting students, parents and based on the resources available (Law on National Education no. l/2011, art. 65,5).

Within the Romanian National Curriculum, the optional disciplines have a proportion of $20 \%$ in the framework plans for the compulsory education and of $30 \%$ in those for high schools (Law on National Education no. l/2011, art. 66,4).

Optional disciplines are included in those teachers' teaching load, who can prove their competence in the chosen area (disciplines that are mentioned in the transcript attached to 
\begin{tabular}{l|l} 
PROBLEMS \\
OF EDUCATION \\
IN THE 21 $1_{\text {st CENTURY }}$ \\
Volume 62, 2014 \\
23
\end{tabular}

\section{Research Focus}

The first years of the implementation of the educational reform, 1998 - 2000, when the optional disciplines were introduced, were defining for their role and status, but later, this very role and status became unclear and uncertain. Due to the completely new situation, several inherent difficulties arose soon, which required and imposed a quick change in mentality, both at the level of decision makers (school directors, inspectors etc.) and at that of teachers. At the beginning, teachers were not at all keen on teaching optional disciplines. Many of them still consider it a burden to teach an optional discipline and they do that only when they have no other options. They prefer classes dedicated to deepening and widening contents of the core curriculum.

It is true that teachers have the main role in organising the teaching of optional disciplines. They find themselves in the exclusive position of curriculum creators, which means drawing on their competences in order to create learning situations that have not been prescribed by others. On the other hand, the curriculum creator teacher facilitates the students' relationship with learning techniques and resources, as well as self-knowledge tools, guiding them in this way towards their professional life. Teaching truly new, or relatively new, curricular areas, such as civic education, entrepreneurship education, CIT etc., included in the curriculum as crosscurricular disciplines or integrated into other disciplines, requires special approaches, as well as changes in the school culture and in the way it is organised. In addition, teaching optional disciplines requires teachers who work closely together and who go beyond the boundaries of traditional disciplines. In practice this means that teachers should work together on developing the school curriculum, or parts of it, discuss assessment standards and exchange information on students' learning progress.

\section{Methodology of Research}

\section{Research Objectives}

The aim of the research was to determine the way in which optional disciplines can contribute to the development of transferable competences in students. The study was carried out from May 2014 to September 2014. The specific objectives of the research were the following: (1) identifying teachers' attitude towards the role of optional disciplines in developing transferable competences, (2) identifying institutional policies on selecting and approving optional disciplines, (3) identifying the teachers' opinion, depending on their teaching certification, on the usefulness of optional disciplines. The hypothesis of the research was that there is a strong correlation between the teachers' willingness to teach optional disciplines (a prerequisite for developing transferable competences in students) and their level of psycho-pedagogical and methodological training.

\section{The Sample of Research}

The sample of the research consisted of 112 participants $(\mathrm{N}=112)$, all of them teachers from pre-university educational institutions from Romania. The participants included in the sample were chosen using the simple random sampling procedure, and they belonged to the following categories: according to the school stage: $60 \%$ primary school teachers and $40 \%$ secondary school teachers, according to years of teaching: less than 5 years $-53,57$, more than 5 years $46,43 \%$, according to the certifications obtained: beginner teachers and those with a full-time professional degree $-14 \%$, teacher certification level $2-64 \%$, teacher certification level I $-22 \%$. 
PROBLEMS

OF EDUCATION

IN THE $21^{\text {st }}$ CENTURY

Volume 62, 2014

24

\section{Instrument and Procedures}

The instrument used in this research was a questionnaire consisting of three parts: the first part included the respondents' personal data, the second one five items on the ways optional disciplines are suggested and selected at school level, and the third part included questions on the teachers' attitude towards the place and role of optional disciplines in the national curriculum. The questionnaire was filled in online by each respondent and the answers were imported into a database that was accessed by the person conducting the research. The questionnaire was prepared and validated by educationalists from the Continuing Education Centre of the University of Oradea.

\section{Data Analyses}

The quantitative interpretation of the results was performed by calculating the statistical frequency of the answers. In addition, the answers given by the respondents belonging to different subcategories of the sample were comparatively analysed according to the professional certification level: beginner, full-time professional degree, teacher certification level 2 or 1 . In order to determine the correlation between the teachers' teaching experience and their willingness to get involved in selecting and teaching optional disciplines, the chi square $\left(\chi^{2}\right)$ criterion was calculated. The statistical processing of the values obtained was performed using the SPSS program.

\section{Results of Research}

The results obtained can be seen in the following tables.

Table 1. The reasons behind selecting optional disciplines included in the SBC.

\begin{tabular}{lllllll}
\hline \multirow{2}{*}{ Indicators } & \multicolumn{2}{l}{$\begin{array}{l}\text { Teachers with } \leq 5 \text { years' teaching } \\
\text { experience }\end{array}$} & $\begin{array}{l}\text { Teachers' with }>5 \text { years' } \\
\text { teaching experience }\end{array}$ \\
\cline { 2 - 7 } & $\begin{array}{l}\text { Uncertain } \\
(\%)\end{array}$ & $\begin{array}{l}\text { Agree } \\
(\%)\end{array}$ & $\begin{array}{l}\text { Strongly } \\
\text { agree }(\%)\end{array}$ & $\begin{array}{l}\text { Uncertain } \\
(\%)\end{array}$ & $\begin{array}{l}\text { Agree } \\
(\%)\end{array}$ & $\begin{array}{l}\text { Strongly } \\
\text { agree }(\%)\end{array}$ \\
\hline Students' preferences & 0 & 6.67 & 11.67 & 0 & 8.33 & 5 \\
\hline Parents' preferences & 0 & 5 & 1.67 & 0 & 8.33 & 3.33 \\
\hline The options of the local community & 0 & 5 & 5 & 0 & 11.67 & 8.33 \\
\hline Students' preoccupations & 0 & 3.33 & 13.33 & 0 & 11.67 & 11.67 \\
\hline Needs of the European education & 0 & 8.33 & 15 & 0 & 0 & 8.33 \\
\hline $\begin{array}{l}\text { Personal preferences and preoc- } \\
\text { cupations }\end{array}$ & 0 & 8.33 & 16.67 & 0 & 0 & 10 \\
\hline
\end{tabular}

As far as the reasons behind selecting optional disciplines for the SBC are concerned, it can be seen that there are some differences between the two categories of teachers included in the research. Thus, while those with less than 5 years' teaching experience consider that these needs are: their personal preferences and preoccupations, the needs of the European education, the students' preferences and preoccupations, those with more teaching experience place as first indicator the students' preoccupations and preferences, followed by the options of the local community. The answers of the teachers with more teaching experience show a certain awareness of the place and role of school in the life of the local community and its connection to the labour market. It is good to see that, regardless of their teaching experience, the teachers stay connected to the needs, preferences and aspirations of students. 
Table 2. Criteria for selecting an optional discipline for a SBC.

\begin{tabular}{|c|c|c|c|c|}
\hline \multirow[b]{2}{*}{ Indicators } & \multicolumn{2}{|c|}{$\begin{array}{l}\text { Teachers with } \leq 5 \text { years' teaching } \\
\text { experience }\end{array}$} & \multicolumn{2}{|c|}{$\begin{array}{l}\text { Teachers' with }>5 \text { years' teaching } \\
\text { experience }\end{array}$} \\
\hline & $\begin{array}{l}\text { Beginner } \\
(\%)\end{array}$ & $\begin{array}{l}\text { Full-time professional } \\
\text { degree (\%) }\end{array}$ & $\begin{array}{l}\text { Certification level } \\
2(\%)\end{array}$ & $\begin{array}{l}\text { Certification level } \\
1(\%)\end{array}$ \\
\hline $\begin{array}{l}\text { Need to complete some teaching } \\
\text { loads }\end{array}$ & 18.33 & 38.33 & 21.15 & 25 \\
\hline $\begin{array}{l}\text { The status of the discipline in the } \\
\text { curriculum }\end{array}$ & 8.33 & 13.33 & 11.54 & 21.15 \\
\hline The students' interests & 3.33 & 6.67 & 3.85 & 1.92 \\
\hline The facilities of the school & 3.33 & 8.33 & 5.77 & 9.62 \\
\hline
\end{tabular}

It can be seen from Table 2, that the first criterion for selecting an optional discipline is the need to complete some teaching loads $(56.66 \%$ in the case of teachers with less than 5 years' teaching experience and $46.15 \%$ for those with more than 5 years' teaching experience). This aspect should be taken into account by decision makers in schools, the more so as teachers' certain reluctance to suggest new disciplines is due to it. A high number of the teachers with more than 5 years' teaching experience consider that some disciplines are "favoured" by decision makers' (this is particularly true for those disciplines that are taught in only 1 or 2 hours per week; in the smaller schools it is hard to complete the teaching load of those teachers who teach such subjects and, in order to help these teachers, the decision makers often choose optional monodisciplinary disciplines that are derived from the disciplines concerned). There are also situations in which the optional discipline does not belong to the students' scope of interest, or when the school does not have the facilities needed to implement a certain optional discipline. In such cases the decision makers of the school do not approve optional disciplines suggested by the teachers.

Table 3. The usefulness of optional disciplines in developing transferable competences.

\begin{tabular}{lllllll}
\hline & \multicolumn{2}{l}{$\begin{array}{l}\text { Teachers with } \leq 5 \text { years' teaching } \\
\text { experience }\end{array}$} & \multicolumn{3}{l}{$\begin{array}{l}\text { Teachers with }>5 \text { years' teaching } \\
\text { experience }\end{array}$} \\
\cline { 2 - 7 } Indicators & $\begin{array}{l}\text { Uncertain } \\
(\%)\end{array}$ & $\begin{array}{l}\text { Agree } \\
(\%)\end{array}$ & $\begin{array}{l}\text { Strongly } \\
\text { agree }(\%)\end{array}$ & $\begin{array}{l}\text { Uncertain } \\
(\%)\end{array}$ & $\begin{array}{l}\text { Agree } \\
(\%)\end{array}$ & $\begin{array}{l}\text { Strongly } \\
\text { agree }(\%)\end{array}$ \\
\hline $\begin{array}{l}\text { The optional disciplines help an in- } \\
\text { tegrated approach to the curriculum }\end{array}$ & 0.0 & 1.8 & 98.2 & 0.0 & 29.6 & 70.4 \\
\hline $\begin{array}{l}\text { Optional disciplines are useful for } \\
\text { developing inter- and transdiscipli- } \\
\text { nary competences in students }\end{array}$ & 0.0 & 2.7 & 97.3 & 0.0 & 30.1 & 69.9 \\
\hline $\begin{array}{l}\text { Optional disciplines help the } \\
\text { development of transferable compe- } \\
\text { tences in students }\end{array}$ & 0.0 & 4.2 & 95,8 & 0.0 & 34.4 & 65.6 \\
\hline
\end{tabular}

The indicators of the table refer to the importance of optional disciplines in developing transferable competences. As it has already been mentioned earlier, these competences are developed in an integrated way, that is, in an inter- and transdisciplinary one. In order to em- 
PROBLEMS

OF EDUCATION

IN THE $21^{\text {st }}$ CENTURY Volume 62,2014

26

phasise this connection, three indicators were analysed. The results presented in the table show that the teachers are aware of these aspects, since the answers expressed in percentages are very close to each other. There is, however, a slight difference between the teachers with less than 5 years' teaching experience and those with more than 5 years' teaching experience. In the case of the first category, the strongly agree column has values of more than $95 \%$, while in the case of the second one, these values exceed $65 \%$. This shows that the teachers who are at the beginning of their career are more enthusiastic, more willing to adjust to an ever-changing reality, but also that they are much more familiar with everything that means technological development, foreign language skills etc., which are all aspects strongly connected to transferable competences. These teachers feel ready to teach disciplines that will prepare the students for a career and for life. On the other hand, the teachers with more teaching experience show a certain reluctance to face those challenges, new experiences which come along with the rapid changes in society.

Table 4. The correlation between teaching experience and the teachers' willingness to get involved in teaching optional disciplines.

\begin{tabular}{lll}
\hline Indicator & $\begin{array}{l}\text { Teachers with } \leq \mathbf{5} \text { years' } \\
\text { teaching experience }\end{array}$ & $\begin{array}{l}\text { Teachers with }>\mathbf{5} \text { years' teaching } \\
\text { experience }\end{array}$ \\
\hline $\begin{array}{l}\text { The teachers willingness to get involved in } \\
\text { teaching optional disciplines }\end{array}$ & $\begin{array}{l}\chi^{2}=1.29 \\
p<0.01\end{array}$ & $\begin{array}{l}\chi^{2}=35.29 \\
p<0.05\end{array}$ \\
& &
\end{tabular}

The table above shows clearly the correlation between teaching experience and the teachers' willingness to get involved in teaching optional disciplines. Thus, while the significance of $\chi^{2}$ is maximum $(\mathrm{p}<0.01)$ in the case of the beginner teachers, the ones with less than 5 years' teaching experience, it decreases a bit, keeping though its significance $(p<0.05)$ in the case of those with more than 5 years' experience. This means that the hypothesis of the research was confirmed. It can be said that, on the one hand, the teachers with less than 5 years' teaching experience have fresh knowledge in the field of psycho-pedagogy and methodology, and, on the other hand, they feel much better connected to an ever-changing reality. At the same time, their colleagues with more than 5 years' teaching experience can be seen as having an older and, perhaps, outdated psycho-pedagogical and methodological training. In their case, routine leads sometimes to the lack of enthusiasm and to reluctance to take part in continued training, and that has a direct impact on their teaching activity.

\section{Discussion}

A first aspect that should be discussed is that of the importance of optional disciplines in school. Articles published in the scholarly literature (Mason, 2009, Hansen \& Svedin, 2009, Leask \& Bridge, 2013) have pointed out that in recent decades, due to the complexity of the world we live in, the need for moving from a monodisciplinary approach towards a transdisciplinary one has become stronger and stronger. This means that schools require contextualized curricula, which go beyond the development of competences that are specific to only one discipline. In Romania, education is traditionally strongly based on disciplines. At the same time, it can be often seen that the decision of the School Board on accepting new disciplines suggested by the teachers as optional ones, which promote integrated learning activities, is made taking into account the need to complete teaching loads (and based less on the students' interests, the facilities of the school, discussions with parents, interaction with the European education etc.). As a result, there are many teachers who feel that the way these disciplines are selected is unfair, just like the offer presented later to the students. However, it is good to see that there are many teachers who are willing to teach an optional subject, which would develop competences for life in students and contribute in this way to the development of their personality. 
A second aspect that is worth discussing is the importance of optional disciplines in developing transferable competences in students. Research done in this field (Caires \& Almeida, 2005, Sicilia, 2009, Pepper, 2011) has highlighted that interpersonal abilities, those of working in a team, of learning, of communication or of computing should be essential items of any training models. These transferable competences cannot always develop within a discipline. This research has showed that the majority of the teachers consider that optional disciplines can develop transferable competences. It has also clearly pointed out that young teachers, those at the beginning of their career, being more connected to everything that means technological development, are more willing to teach disciplines that exploit new learning situations, which are aimed at preparing students for a career and for life, than the teachers with more than 5 years' teaching experience, who are more reluctant to face new challenges and are sometimes stuck in routine.

\section{Conclusions}

In the Romanian education system, still centred on approaching contents at the level of one discipline, SBC could mean moving towards an integrated approach to contents, which would broaden the possibility of developing transferable competences. Only in this way will education meet the increased requirements of a knowledge-based society (Blândul, 2010, p. 122), and students become autonomous personalities, capable of socio-professional integration.

The research proved that the teachers are aware of the importance of optional disciplines and know the obstacles they will face when they try to make the curriculum more flexible (personalisation, orientation towards developing transferable competences). First and foremost, it is recommended that decision makers in Romanian schools observe the methodology in force concerning the implementation of SBC. At the same time, building a positive socioprofessional environment that is based on trust, collaboration, reflexivity, proactive attitude, is also strongly recommended. The result will be a greater variety of optional disciplines, that is, disciplines that go beyond the borders of formal education and expand into various non-formal and informal contexts.

The value added by this research is represented by its focus on the connection between teaching optional disciplines and developing transferable competences in the Romanian preuniversity education, an aspect that has been poorly discussed in the Romanian scholarly literature. This research has brought it in the foreground. As far as the future is concerned, the aim is to extend the research to the field of cross-curricular optional disciplines, those that are taught by teams of teachers, in order to assess the way in which they can contribute to developing transferable competences in students.

\section{References}

Blândul, V. (2010). Intercultural competency - key approach for a United Europe. In Marcu, V. \& Bradea, A. (Eds.), The approach of interculturality in multiethnic education. Oradea: Oradea University Press.

Caires, S., \& Almeida, L. S. (2005). Teaching practice in initial teacher education: its impact on student teachers' professional skills and development. Journal of Education for Teaching: International Research and Pedagogy, 31 (2), 111-120.

CIDREE (1998). Across the great divides. Report on the CIDREE Collaborative project on crosscurricular themes, Consortium of Institutions for Development and Research in Education in Europe, Scottish Consultative Council on the Curriculum, Dundee.

Ciolan, L. (2008). Integrated learning. Foundations for a transdisciplinary curriculum. Iaşi: Polirom.

Crutzen, D. (2005). Les compétences transversales. Un concept-clé pour l'éducation a la diversité en Europe. Quelle realité en Communauté française? In J. Aden (Ed.) De Babel à la mondialisation: apport des sciences sociales à la didactique des langues. CNDP-CRDP de Bourgogne, coll. Documents, actes et rapports pour l' éducation. 
Adela BRADEA, Karla PETER. The Role of Optional Disciplines in Developing Transferable Competences: A Case of Romania

PROBLEMS

OF EDUCATION

IN THE $21^{\text {st }}$ CENTURY

Volume 62,2014

28 Hansen, J. A., \& Svedin, U. (2009). Quality issues in cross $\square$ disciplinary research: towards a two $\square$ pronged approach to evaluation. Social Epistemology: A Journal of Knowledge, Culture and Policy, 23 (2), 165-176.

Grundy, C. (1987). Curriculum: product or praxis. Lewes: Falmer.

Leask, B., \& Bridge, C. (2013), Comparing internationalisation of the curriculum in action across disciplines: theoretical and practical perspectives. Compare: A Journal of Comparative and International Education, 43 (1), 79-101.

Mason, J. (2009). Teaching as disciplined enquiry. Teachers and Teaching: Theory and Practice, 15 (2), 205-223.

Parlamentul României - Camera Deputaților. (2011). Legea Educației Naționale Nr.1/2011. Monitorul Oficial al României, 179 (18), 1-63. București: Regia Autonomă „Monitorul Oficial”. Retrieved 15/10/2014 from http://www.sindicat.uaic.ro/legislatie/LEN_2011.pdf

Pepper, D. (2011). Assessing key competences across the curriculum - and Europe. European Journal of Education, 46 (3), 335-353.

Sicilia, M. A. (2009). How should transversal competence be introduced in computing education? ACM SIGCSE Bulletin, 41 (4), 95-98.

Skilbeck, M. (1984). School based curriculum development. London: Paul Chapman Publishing Ltd.

Voiculescu, F. (2011). The paradigm of approaching through competences. Published within the European POSDRU (Sectoral Operational Programme for the Development of Human Resources) "Quality, Innovation, Communication in the system of continued formation of academic people". Alba-Iulia.

Advised by Valentin Cosmin Blândul, University of Oradea, Oradea, Romania

Received: September 30, 2014

Accepted: November 10, 2014

\begin{tabular}{|ll|}
\hline Adela Bradea & $\begin{array}{l}\text { PhD., Lecturer, University of Oradea, } 1 \text { University Street, Oradea, 410087, Bihor, Romania } \\
\text { E-mail: adelabradea@yahoo.com } \\
\text { Website: http://www.uoradea.ro/ }\end{array}$ \\
\hline \multirow{2}{*}{ Karla Peter } & $\begin{array}{l}\text { PhD., Lecturer, University of Oradea, } 1 \text { University Street, Oradea, 410087, Bihor, Romania } \\
\text { E-mail: karla_barth@yahoo.com } \\
\text { Website: http://www.uoradea.ro/, http://www.socioumane.ro/ }\end{array}$
\end{tabular}

